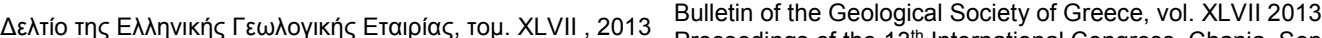
Proceedings of the $13^{\text {th }}$ International Congress, Chania Sept.

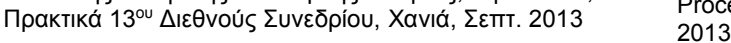

\title{
ANALYSIS OF RELATIONSHIPS AMONG COASTAL ALLUVIAL FANS AND THEIR CONTRIBUTING CATCHMENTS IN NORTH EVOIKOS GULF (CENTRAL GREECE)
}

\author{
Valkanou K. ${ }^{1}$, Karymbalis E. ${ }^{1}$, Papanastassiou D. ${ }^{2}$, Gaki-Papanastassiou K. ${ }^{3}$ \\ and Giles $\mathbf{P}^{4}$ \\ 'Department of Geography, Harokopio University, Athens, Greece (kvalkanou@hua.gr; \\ karymbalis@hua.gr) \\ ${ }^{2}$ Institute of Geodynamics, National Observatory of Athens, Greece (d.papan@noa.gr) \\ ${ }^{3}$ Department of Geography-Climatology, Faculty of Geology \& Geoenvironment, National \\ Kapodistrian University of Athens, Greece (gaki@geol.uoa.gr) \\ ${ }^{4}$ Department of Geography, Saint Mary's University, Halifax, Nova Scotia, Canada
}

\begin{abstract}
This paper deals with the morphometric analysis of 42, late Holocene, coastal alluvial fans located along the coasts of the tectonically active North Evoikos Gulf in central Greece. Thirty six of the fans have been formed by streams that discharge along the east coast of the Gulf (Evia Island) while the rest are located on the opposite side (Continental Greece). Selected morphometric parameters of the drainage basins were measured using topographic maps at the scale of 1:50,000 while those of the fans were derived from detailed topographic diagrams at the scale of 1:5,000 utilizing ESRI's ArcGIS9.3 software. Fans were classified into four groups according to the primary depositional processes (fluvial and/or debris flow). Another classification criterion was the relationship between the location of the fan-catchment system and the local tectonic patterns (active faults). Fan-basin morphometric relationships for each fan group were also investigated. A strong positive relation was found between the size of the fan and the drainage basin area while the correlation between drainage area and fan slope was negative. Large catchments located near fault terminations have formed gently sloping fans dominated by fluvial processes, whereas torrents with small rough drainage basins, developed on the footwall, have formed steep fans likely dominated by debris-flow along the east coast of the Gulf. Key words: Coastal alluvial fans, Quantitative Geomorphology, North Evoikos Gulf, Greece.
\end{abstract}

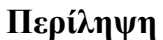

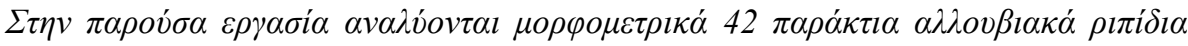

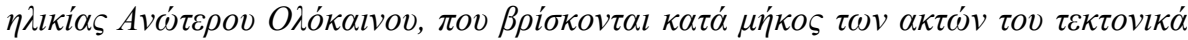

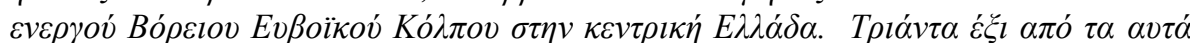


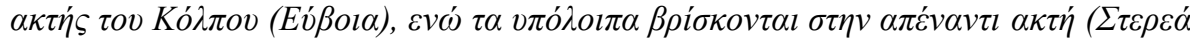

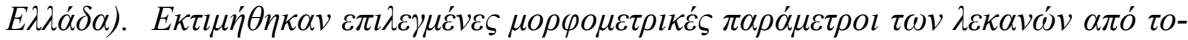

XLVII. No $1-344$ 


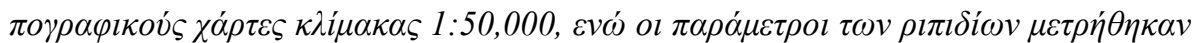

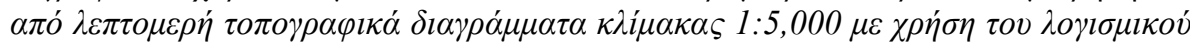

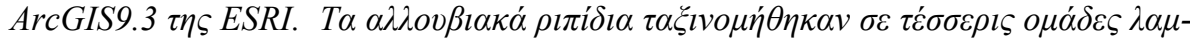

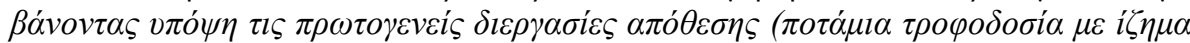

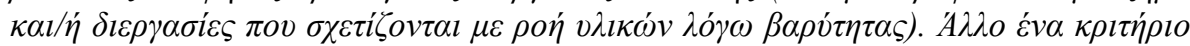

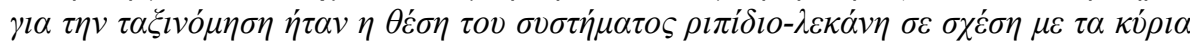

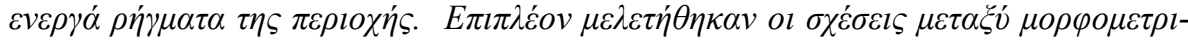

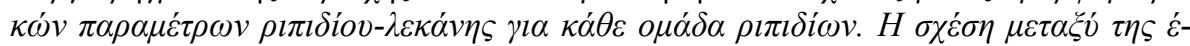

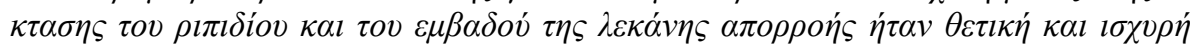

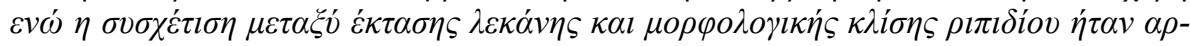

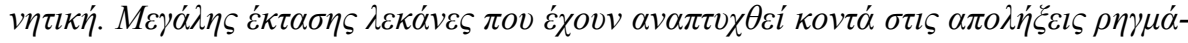

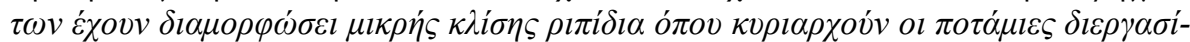

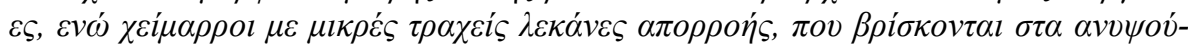

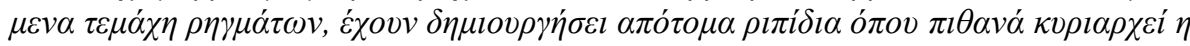

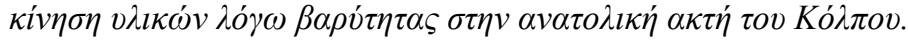

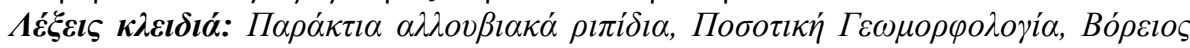
Evßö̈кó $K o ́ \lambda \pi o \varsigma, ~ E \lambda \lambda \alpha ́ \delta \alpha$.

\section{Introduction}

Alluvial fans are sedimentary deposits with a form resembling the segment of a cone radiating downslope from a point where a channel emerges from an upland (Blair and McPherson, 1994). Fans are subaerial features; however, if they extend into water, they are called fan deltas.

According to Blair and McPherson (1994), there are three necessary conditions for optimal alluvial fan development: (a) a topographic setting where a channel becomes unconfined by emerging from an upland drainage basin to a relatively flat lowland, (b) sufficient sediment production in the drainage basin for fan construction, and (c) infrequent intense precipitation to create high water discharge needed to transport the sediment from the drainage basin to the fan site.

The aim of this study is to classify the fans according to the primary depositional processes (fluvial and/or debris flow) controlling their formation and recent evolution, through quantitative morphometry. Among the principal objectives of this paper is to present fan-basin morphometric relationships for the fans, and to investigate the possible relationship between the geographic distribution of fans and basins and the local tectonic patterns.

In Greece, similar attempts have been made to classify fan-deltas along the coast of the Gulf of Corinth (Karymbalis, 2007; Karymbalis et al., 2010; Karymbalis et al., 2012).

\section{Study Area}

The studied fans are located on the east and west coasts of the North Evoikos Gulf, a NW-SE trending graben, $100 \mathrm{~km}$ long, which separates north Evia Island to the east from continental Greece to the west (Figure 1). The Gulf of Evia rift system is a significant geomorphological feature, a Quaternary structure accommodating N-S crustal extension in Central Greece (Roberts \& Jackson, 1991). The amount of extension (from geodetic estimates for the whole of Central Greece) is about $1 \mathrm{~cm} / \mathrm{yr}$, implying a fast mean extension rate (Ganas \& Papoulia, 2000). Recent research using local seismological networks has demonstrated that in this area seismic stress may not necessarily be released with strong earthquakes, but instead with intense microearthquake activity, usually in seismic swarms (Papanastassiou et al., 2001; Papoulia et al., 2006). Several major normal fault zones, in a step-like arrangement striking WNW-ESE and dipping to the north bound the high relief along both coasts. According to Goldsworthy and Jackson (2001) the coastal fault system (Atalanti and Kandili fault zones) is probably the most active and recent (Figure 1). Apart 
from these major coastal faults, there are also NE-SW minor fault zones with motions during the Quaternary (Palyvos, et al., 2006).

The coastal landscape of the west coast of the Gulf has undergone significant changes during the Quaternary which can be recognized in the form of raised terraces, raised or submerged beachrocks and marine notches while on the lowlands tsunami deposits are found (Cundy et al. 2000; Gaki-Papanastassiou et al. 1999). The central-eastern mainland of Greece is a tectonically active region which hosts well-known WNW-ESE tectonic structures, such as the Atalanti, Arkitsa-Agios Konstantinos-Kamena Vourla and Kallidromon Fault zones (Ganas \& White, 1996)

Some historical earthquakes are known in the region from historical sources and archaeological findings, but most cannot be associated with a particular fault. Only one, in 1894, is known to have ruptured the surface and this occurred on the coastal fault system east of Atalanti (Goldsworthy and Jackson, 2001; Goldsworthy et al., 2002; Pantosti et al., 2004; Pavlides et al., 2004). According to Goldsworthy and Jackson, (2001), hanging wall migration of the faulting has occurred, while they maintain that the basins in the Gulf of Evia (Evoikos Gulf) can change from substantial subsidence to substantial uplift, erosion and re-deposition all within 1 million years.

The west coastal zone of North Evoikos Gulf, along the hanging wall of the Arkitsa fault, is dominantly erosional (probably due to sediment starvation), with deposition confined to moderate to large fan deltas (Cundy et al., 2010), while on the other hand the footwall sourced fan deltas of the east side are generally smaller (Leeder and Jackson, 1993).

At the east coastal zone of North Evoikos Gulf the attitude of the normal faults switches from dominantly N-dipping near Kamena Vourla in the west, to S-dipping and then finally to N-dipping along the coastline of NE Evia (Goldsworthy et al., 2002). Normal faults along the east coast of Evoikos Gulf are responsible for uplifted marine notches containing lithophaga (also along the coastline of NE coastline of Evia) (Stiros et al., 1992). No modern earthquakes have occured in this region but several historic events are noted.

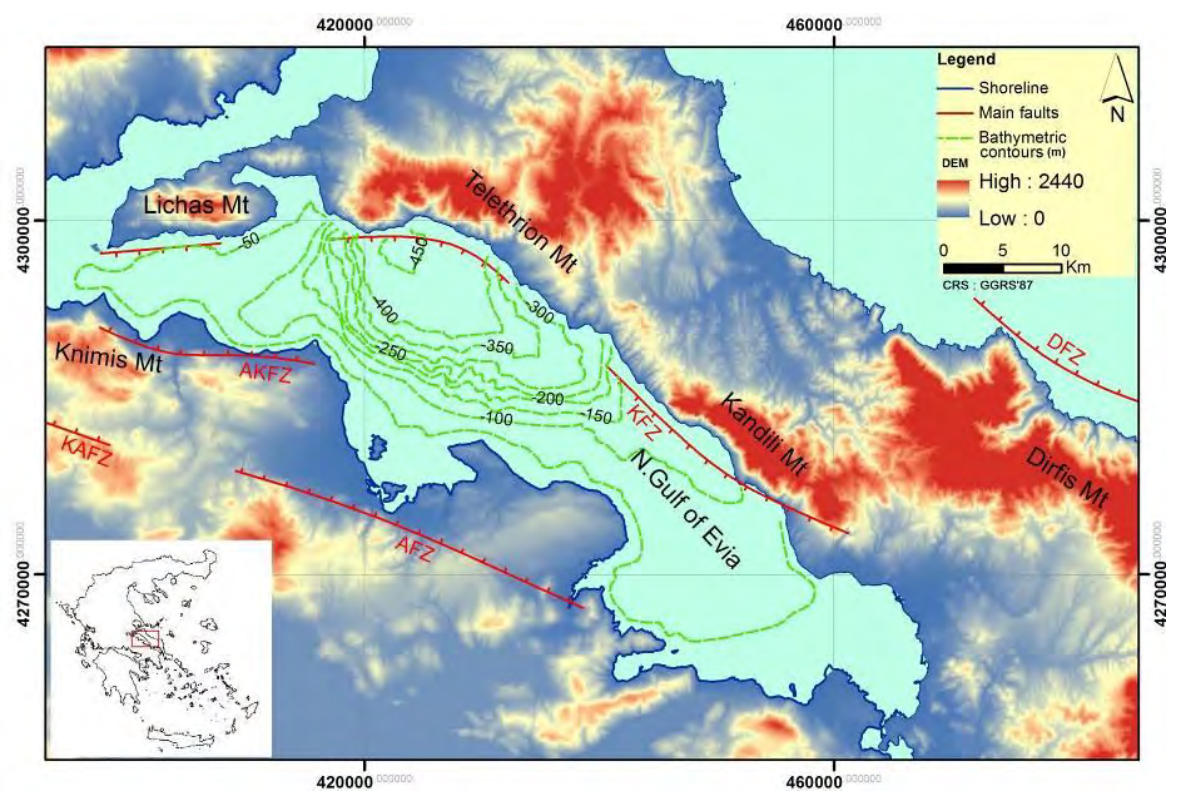

Figure 1 - DEM of the broader area of North Evoikos Gulf. The main normal faults and the subaqueous morphology are also depicted (DFZ: Dirfys fault zone, KFZ: Kandili f.z, AFZ : Atalanti f.z, KAFZ: Kallidromon f.z, AKFZ: Arkitsa-Kammena Vourla f.z) (insert map of Greece shows the location of the study area). 


\section{Data Used and Methodology}

The identification and delineation of the fans was based on field observations, aerial photo interpretation (at 1:33,000 scale, taken in 1996, obtained from the Greek Ministry of Rural Development and Food), and the use of detailed topographic maps (at 1:5,000 scale with $2 \mathrm{~m}$ contour lines) obtained from the Hellenic Geographical Military Survey and geological maps of the sub-aerial geology obtained from the Institute of Geology and Mineral Exploration of Greece (IGME). These detailed topographic maps were also the source for the measurement of fan morphometric variables. Measurement of fan morphometric parameters was restricted to the portion of fan sediments above sea-level since the subaqueous portions could not be measured due to the lack of detailed hydrographic data.

Drainage networks and source catchments were delineated from topographic maps at 1:50,000 scale, with $20 \mathrm{~m}$ contour intervals, and aerial photo interpretation (at 1:33,000 scale, taken in 1996). The same maps were used for the measurement of the morphometric parameters of the catchments. Measurements, calculations and visualization of the results were performed using ESRI's ArcGIS9.3 software.

The morphometric parameters for the fans and their catchments, which provided the most interesting results, are given below:

- Drainage basin area $\left(\mathrm{A}_{\mathrm{b}}\right)$, the total planimetric area of each basin, measured in $\mathrm{km}^{2}$.

- Drainage basin slope $\left(\mathrm{S}_{\mathrm{b}}\right)$, obtained using the equation e $\Sigma \mathrm{Lc} / \mathrm{Ab}$, where e=equidistance, $\mathrm{L}=$ total length of contour lines and $\mathrm{A}_{\mathrm{b}}=$ basin area.

- Drainage basin crest $\left(\mathrm{C}_{\mathrm{b}}\right)$, the maximum elevation of the drainage basin, measured in $\mathrm{m}$.

- Drainage Basin Perimeter $\left(\mathrm{P}_{\mathrm{b}}\right)$, the length of the basin border, measured in $\mathrm{km}$.

- Length of channels $\left(\mathrm{L}_{\mathrm{c}}\right)$, the total length of the channels within the drainage basin, measured in $\mathrm{km}$.

- Drainage basin Relief $\left(\mathrm{R}_{\mathrm{b}}\right)$, the vertical difference between the basin crest and fan apex, given in $\mathrm{m}$.

- Melton's ruggedness number $(\mathrm{M})$, obtained using the formula $\mathrm{R}_{\mathrm{b}} * \mathrm{~A}_{\mathrm{b}}{ }^{-0.5}$.

- Drainage basin circularity $\left(\mathrm{Cir}_{b}\right)$, obtained using the formula $4 \pi \mathrm{A}_{b} / \mathrm{Pb}^{2}$.

- Drainage basin density $\left(\mathrm{D}_{\mathrm{b}}\right)$, the ratio of the total length of the channels to the total area of the basin, $\mathrm{L}_{\mathrm{c}} / \mathrm{A}_{\mathrm{b}}$.

- Total length of $20 \mathrm{~m}$ contour lines within the drainage basin $\left(\Sigma \mathrm{L}_{\mathrm{c}}\right)$, measured in $\mathrm{km}$.

- Fan area $\left(\mathrm{A}_{\mathrm{f}}\right)$, the total planimetric area of each fan, measured in $\mathrm{km}^{2}$.

- Fan apex $\left(\mathrm{Ap}_{\mathrm{f}}\right)$, the elevation of the apex of the fan, in $\mathrm{m}$.

- Fan length $\left(\mathrm{L}_{\mathrm{f}}\right)$, the distance between the toe (in our case coastline) and apex of the fan, measured in $\mathrm{m}$.

- Fan slope $\left(\mathrm{S}_{\mathrm{f}}\right)$, the mean gradient measured among the axial part of the fan.

- Fan concavity $\left(\mathrm{C}_{\mathrm{f}}\right)$, obtained using the formula $\mathrm{a} / \mathrm{b}$, where $\mathrm{a}=$ the elevation difference between the fan axis profile and the midpoint of the straight line joining the fan apex and toe and $b=$ the elevation difference between the fan toe and the midpoint.

The relationships between selected basin and fan parameters were investigated by plotting log-log graphs and determining the power functions that describe these relations. 


\section{Geological Background}

The Alpine basement of the catchments consists of the geological formations of the Pelagonian geotectonic zone. According to the geological mapping of the Institute of Geology and Mineral Exploration of Greece - IGME - the formations of the Alpine basement of the study area is composed of igneous rocks (intrusives such as diabases, peridotites, dunites, pyroxenites and ophiolites), Upper Paleozoic greenschists, schists, phyllites, and greywackes with conglomerates and limestone or dolomite intercalations, Permo-Triassic limestones, greywackes, schists, prasinites and volcanites. Trias and Jurassic are primarily represented by limestones and dolomites while schist-chert formation (including radiolarites, sandstones, pelites with limestone lenses and enclosed ophiolitic bodies) of Jurrassic age also occur in the study area. The younger Alpine rocks are limestones (mainly biosparudites), crystalline limestones and marbles of Upper Cretaceous age.

Post-Alpine formations consist of lacustrine and terrestrial deposits (conglomerates, sands, clayey material, marls and marly limestones) of Upper Miocene-Pliocene age and Plio-Pleistocene fluviolacustrine deposits such as sands, conglomerates, clays, and peat or lignite beds. Valley bottoms along of the major streams are covered by alluvial deposits of Holocene age. The mountainous relief, the numerous torrents and the occurrence of extensive areas covered by erodible formations (e.g., loose Quaternary deposits, Neocene sediments, flysch formation) can amplify the action of the erosion process. As a consequence Evia Island exhibits a high frequency of landslides and represents one of the sites in Greece with the highest landslide susceptibility (Rozos et al., 2013).

In order to investigate the influence of the drainage basin lithology on the evolution of the fans the lithological units cropping out in the catchments were grouped into four classes based on their permeability (IGME, 2010). The first group includes marls and clays, schists, ophiolites, volcanic formations and FeNi deposits. The second group includes limestones, limestone conglomerates, dolomites, sipolines. The third group consists of alluvial sediments, sandstones and travertine; and the fourth group contains clastic sediments and molassic deposits. The relative distribution of each one of the four main lithological types in the area of each basin was estimated and the dominant catchment lithology group has been correlated to the fan area and the fan gradient. This correlation showed that the role of the bedrock control on fan formation processes is not clear, probably because of the complexity of the system.

\section{Classification of the Coastal Fans}

Table 1 includes the values of the morphometric variables estimated for the coastal alluvial fans and their drainage basins. The total number of fans is 42. By far the largest among the fans is Dipotamon having an area of $10.62 \mathrm{~km}^{2}$ (Figure 3). It has developed at the hanging wall of Arkitsa-Kammena Vourla fault zone and can be characterized as a delta, dominated by fluvial supply and wave activity, formed by a relatively large river with perennial flow. The area of the other fans range between 0.01 and $3.78 \mathrm{~km}^{2}$. An important factor for the discrimination between the alluvial fan processes is the size of the drainage basin (represented by the area and the total length of the drainage network channels) (Crosta \& Frattini, 2004). Morphometric parameters of the fans and corresponding basins along with the tectonic setting of the fan-catchment systems were the main criteria for the classification of the fans into the following four groups (Figure 2).

Group 1 includes five fans, four located on Evia Island (7-18-25-35) and fan 41 fan which lies on the opposite side of the Gulf (Figure $2 \&$ Figure 3). These have been developed laterally and partially cover larger fluvial-dominated fans of the other groups. Their shape is conical and they do not have well-developed channels. These fans are small (mean fan area is $0.09 \mathrm{~km}^{2}$ ) with small catchments (mean basin area is $1.05 \mathrm{~km}^{2}$ ). Fan gradients for this group are high (mean fan slope equals 0.09). Their morphology, as well as the morphometric characteristics of their catchments, indicates that they are likely debris flow-dominated fans. 
Group 2 contains 22 fans (1-2-3-4-5-6-8-15-16-17-19-20-21-22-23-24-26-30-31-32) on Evia Island, and fans 37 and 38 on the west side of the Gulf (Figure $2 \&$ Figure 3). The main characteristic of this group's fans is their tectonic setting. Both fans and drainage basins are situated on the footwall of the main active normal faults which tend to be parallel to the east and west coast of the Gulf. Both fans and catchments of this group are more extensive than those of the previous group (mean area values are $0.33 \mathrm{~km}^{2}$ and $4.09 \mathrm{~km}^{2}$ respectively) whereas fans are less steep (mean fan slope equals 0.07). Most of them have a triangular shape and are characterized as fluvialdominated.

Group 3 is comprised of ten fans (9-10-11-12-13-14-27-28-29-36) (Figure 2 \& Figure 3), which have developed along the coastline of the Evia Island. Fan-catchment systems of this group are not directly affected by major faults as they lie between fault segments or near their terminations. This type of tectonic setting provides enhanced opportunities for drainage growth (Leeder and Jackson 1993). These fans have a more semicircular morphology and are generally aggrading fans with an active prograding area near the river mouth. They are more extensive than the previous group (mean fan area is $0.68 \mathrm{~km}^{2}$ ) and have more extensive catchments (mean basin area is $9.95 \mathrm{~km}^{2}$ ). They are characterized as fluvial-dominated.

Group 4 includes five fans (33-34 on Evia Island and 39-40-42 on the west side of the Gulf) (Figure $2 \&$ Figure 3 ). In this category, basins lie on the footwall of active faults while their corresponding fans are on the hanging wall. In this group the fans have the greater mean area $\left(2.87 \mathrm{~km}^{2}\right)$ and the lower mean slope (0.03) and are typical fluvial-dominated fans formed by extensive drainage basins which are located on the uplifting block of active faults.

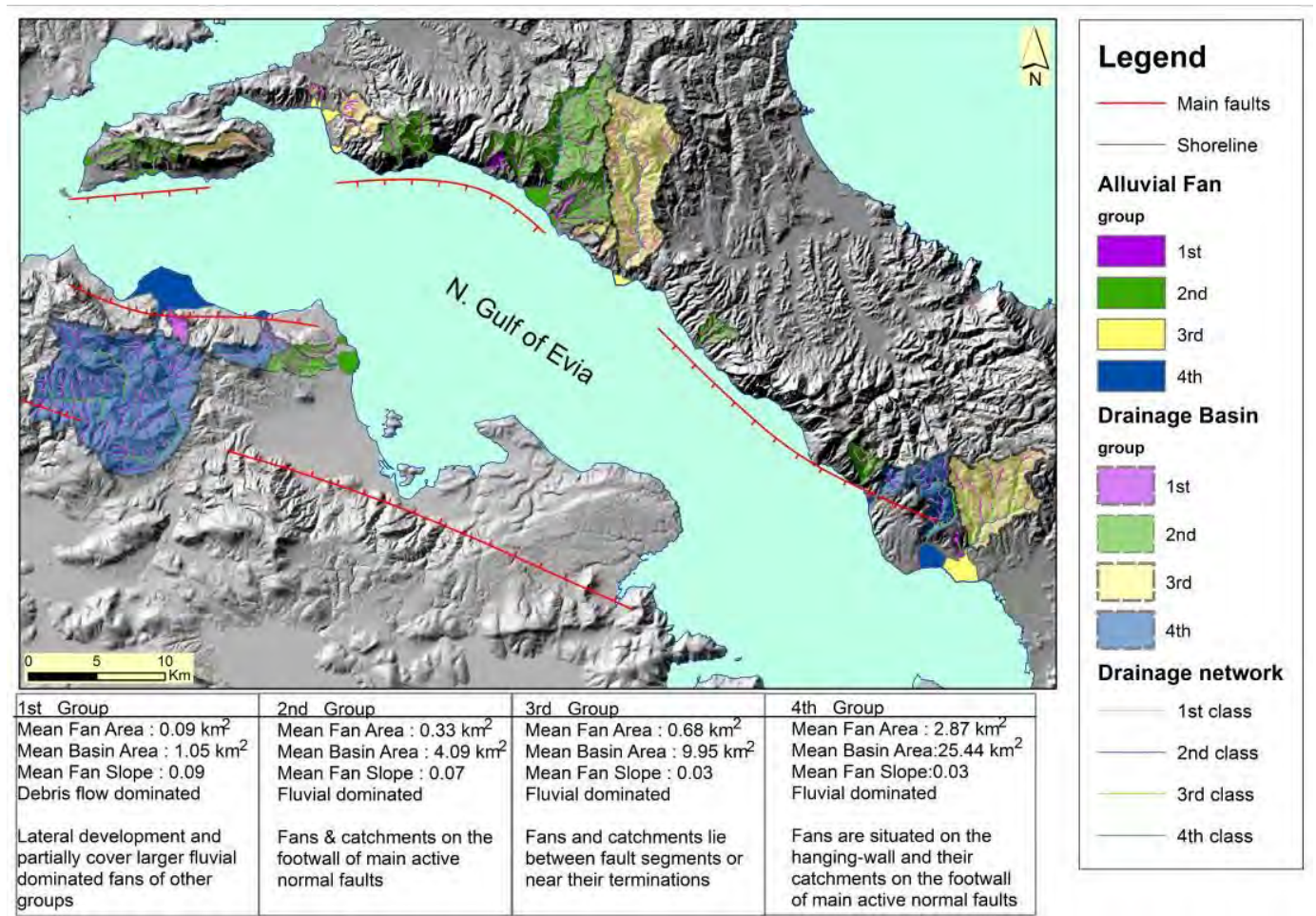

Figure 2 - Hillshade map of the North Evoikos Gulf with the classification of fans and their corresponding catchments into four (4) groups according to the primary depositional processes and their position with respect to the local tectonic pattern. Comments on fan and basin characteristics as well as on their formation and their location are also shown. 
Table 1 - Values of the morphometric parameters for the coastal fans and their drainage ba$\operatorname{sins}$

\begin{tabular}{|c|c|c|c|c|c|c|c|c|c|c|c|c|c|c|c|c|}
\hline & Name & $\mathbf{A}_{b}$ & $\mathbf{P}_{\mathbf{b}}$ & $\mathbf{L}_{c}$ & $\Sigma \mathbf{L}_{c}$ & $\mathbf{D}_{\mathrm{b}}$ & $S_{b}$ & $\mathrm{Cir}_{\mathbf{b}}$ & $C_{b}$ & M & $\mathbf{A p} p_{f}$ & $\mathbf{R}_{\mathrm{b}}$ & $\mathbf{A}_{\mathbf{f}}$ & $\mathbf{L}_{\mathrm{f}}$ & $\mathbf{S}_{\mathrm{f}}$ & $\mathrm{C}_{\mathrm{f}}$ \\
\hline \multirow{5}{*}{ 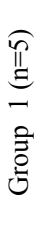 } & 7 & 0.2 & 2.2 & 0.70 & 4.6 & 3.68 & 0.49 & 0.52 & 380 & 0.28 & 20 & 360 & 0.01 & 108.5 & 0.129 & 2.50 \\
\hline & 18 & 1.1 & 4.6 & 1.56 & 35.0 & 1.39 & 0.62 & 0.68 & 810 & 0.69 & 80 & 730 & 0.05 & 409.1 & 0.132 & 1.45 \\
\hline & 25 & 0.8 & 4.2 & 1.50 & 8.3 & 2.00 & 0.22 & 0.53 & 280 & 0.28 & 40 & 240 & 0.12 & 508.8 & 0.055 & 1.33 \\
\hline & 35 & 0.7 & 4.2 & 2.37 & 10.0 & 3.20 & 0.27 & 0.52 & 290 & 0.40 & 48 & 242 & 0.16 & 587.0 & 0.041 & 1.18 \\
\hline & 41 & 2.5 & 7.1 & 4.29 & 50.9 & 1.75 & 0.42 & 0.61 & 630 & 0.36 & 60 & 570 & 0.10 & 313.0 & 0.077 & 0.71 \\
\hline \multirow{22}{*}{$\begin{array}{c}\overparen{N} \\
\mathbb{N} \\
\Xi \\
\sim \\
\approx \\
0 \\
0 \\
0\end{array}$} & 1 & 1.2 & 5.8 & 2.69 & 24.1 & 2.32 & 0.42 & 0.43 & 670 & 0.38 & 20 & 650 & 0.21 & 707.5 & 0.028 & 2.33 \\
\hline & 2 & 3.1 & 8.6 & 6.56 & 39.3 & 2.13 & 0.25 & 0.52 & 670 & 0.15 & 19 & 651 & 0.39 & 709.2 & 0.027 & 0.73 \\
\hline & 3 & 1.1 & 5.4 & 1.93 & 18.9 & 1.77 & 0.35 & 0.47 & 670 & 0.21 & 36 & 634 & 0.31 & 772.1 & 0.047 & 2.00 \\
\hline & 4 & 1.0 & 4.7 & 1.52 & 19.4 & 1.49 & 0.38 & 0.58 & 580 & 0.31 & 41 & 539 & 0.14 & 472.4 & 0.087 & 1.28 \\
\hline & 5 & 2.3 & 8.2 & 3.56 & 43.5 & 1.58 & 0.39 & 0.43 & 690 & 0.41 & 40 & 650 & 0.28 & 529.0 & 0.076 & 1.50 \\
\hline & 6 & 0.3 & 2.6 & 0.93 & 6.6 & 3.10 & 0.44 & 0.55 & 410 & 0.14 & 24 & 386 & 0.03 & 233.6 & 0.103 & 1.18 \\
\hline & 8 & 1.6 & 6.2 & 3.46 & 37.5 & 2.11 & 0.46 & 0.54 & 710 & 0.19 & 40 & 670 & 0.10 & 417.7 & 0.096 & 1.67 \\
\hline & 15 & 4.1 & 10.5 & 6.99 & 75.4 & 1.69 & 0.36 & 0.48 & 890 & 0.32 & 60 & 830 & 0.06 & 469.3 & 0.128 & 1.61 \\
\hline & 16 & 5.5 & 10.3 & 7.76 & 154.3 & 1.42 & 0.56 & 0.65 & 870 & 0.13 & 40 & 830 & 0.16 & 533.9 & 0.075 & 1.11 \\
\hline & 17 & 2.2 & 7.1 & 3.24 & 61.5 & 1.50 & 0.57 & 0.54 & 970 & 0.92 & 36 & 934 & 0.11 & 423.2 & 0.085 & 1.00 \\
\hline & 19 & 0.3 & 2.6 & 2.25 & 10.0 & 7.03 & 0.63 & 0.59 & 650 & 0.89 & 144 & 506 & 0.08 & 731.3 & 0.197 & 1.12 \\
\hline & 20 & 0.3 & 2.7 & 1.97 & 9.9 & 5.97 & 0.60 & 0.56 & 630 & 0.30 & 100 & 530 & 0.05 & 551.3 & 0.181 & 0.92 \\
\hline & 21 & 5.3 & 9.5 & 7.61 & 145.8 & 1.45 & 0.56 & 0.74 & 970 & 0.32 & 100 & 870 & 0.15 & 790.0 & 0.127 & 0.92 \\
\hline & 22 & 32.3 & 27.9 & 58.55 & 664.0 & 1.81 & 0.41 & 0.52 & 930 & 0.35 & 56 & 874 & 1.77 & 2107.7 & 0.027 & 0.70 \\
\hline & 23 & 3.3 & 8.8 & 7.77 & 70.8 & 2.35 & 0.43 & 0.54 & 850 & 0.43 & 62 & 788 & 0.39 & 1132.8 & 0.055 & 1.58 \\
\hline & 24 & 0.4 & 2.8 & 0.84 & 3.8 & 2.40 & 0.22 & 0.58 & 210 & 0.64 & 26 & 184 & 0.15 & 603.6 & 0.043 & 1.17 \\
\hline & 26 & 9.2 & 14.5 & 16.86 & 136.3 & 1.84 & 0.30 & 0.55 & 930 & 0.30 & 20 & 910 & 0.22 & 586.9 & 0.034 & 0.67 \\
\hline & 30 & 2.0 & 6.8 & 3.98 & 44.4 & 1.96 & 0.44 & 0.55 & 350 & 0.60 & 20 & 330 & 0.09 & 533.1 & 0.038 & 1.86 \\
\hline & 31 & 2.0 & 7.0 & 3.25 & 45.9 & 1.67 & 0.47 & 0.50 & 430 & 0.37 & 16 & 414 & 0.03 & 395.6 & 0.040 & 1.29 \\
\hline & 32 & 4.3 & 9.5 & 7.01 & 116.3 & 1.63 & 0.54 & 0.59 & 1090 & 0.83 & 24 & 1066 & 0.02 & 272.9 & 0.088 & 2.00 \\
\hline & 38 & 2.1 & 7.7 & 5.14 & 24.4 & 2.47 & 0.23 & 0.45 & 350 & 0.23 & 20 & 330 & 0.41 & 840.1 & 0.024 & 1.00 \\
\hline & 37 & 6.2 & 13.3 & 11.02 & 70.4 & 1.79 & 0.23 & 0.44 & 440 & 0.16 & 39 & 401 & 2.03 & 1683.1 & 0.023 & 1.44 \\
\hline \multirow{10}{*}{$\begin{array}{c}0 \\
\pi \\
\Xi \\
m \\
0 \\
0 \\
0 \\
0\end{array}$} & 9 & 5.7 & 15.4 & 8.39 & 88.2 & 1.46 & 0.31 & 0.31 & 740 & 0.53 & 20 & 720 & 0.08 & 547.8 & 0.037 & 0.67 \\
\hline & 10 & 0.2 & 2.3 & 0.22 & 4.0 & 1.00 & 0.37 & 0.51 & 200 & 0.30 & 24 & 176 & 0.12 & 556.0 & 0.043 & 0.71 \\
\hline & 11 & 0.7 & 3.5 & 4.99 & 12.7 & 7.13 & 0.36 & 0.70 & 230 & 0.24 & 28 & 202 & 0.33 & 1039.4 & 0.027 & 1.00 \\
\hline & 12 & 0.2 & 1.7 & 1.23 & 2.8 & 7.69 & 0.35 & 0.66 & 110 & 0.22 & 22 & 88 & 0.17 & 839.8 & 0.026 & 1.75 \\
\hline & 13 & 4.0 & 9.2 & 13.48 & 63.1 & 3.37 & 0.32 & 0.59 & 420 & 0.38 & 36 & 384 & 0.94 & 1538.7 & 0.023 & 1.77 \\
\hline & 14 & 3.9 & 10.6 & 8.21 & 87.1 & 2.13 & 0.45 & 0.44 & 670 & 0.70 & 44 & 626 & 0.41 & 973.5 & 0.045 & 0.76 \\
\hline & 27 & 2.2 & 7.6 & 2.54 & 35.9 & 1.16 & 0.33 & 0.47 & 470 & 0.43 & 24 & 446 & 0.13 & 463.3 & 0.052 & 1.40 \\
\hline & 28 & 2.0 & 7.2 & 2.45 & 30.3 & 1.26 & 0.31 & 0.48 & 470 & 0.61 & 24 & 446 & 0.08 & 384.3 & 0.062 & 1.18 \\
\hline & 29 & 48.5 & 36.9 & 81.13 & 888.2 & 1.67 & 0.37 & 0.45 & 930 & 0.52 & 16 & 914 & 0.79 & 1235.5 & 0.013 & 0.78 \\
\hline & 36 & 32.2 & 30.4 & 55.04 & 450.0 & 1.71 & 0.28 & 0.44 & 830 & 0.30 & 36 & 794 & 3.78 & 2863.9 & 0.013 & 1.25 \\
\hline \multirow{5}{*}{ 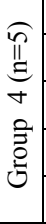 } & 33 & 4.0 & 8.8 & 7.91 & 108.5 & 1.96 & 0.54 & 0.66 & 850 & 0.23 & 40 & 810 & 0.28 & 639.1 & 0.063 & 2.33 \\
\hline & 34 & 14.5 & 20.9 & 25.44 & 259.3 & 1.75 & 0.36 & 0.42 & 850 & 0.51 & 44 & 806 & 2.94 & 1881.1 & 0.023 & 1.20 \\
\hline & 42 & 100.1 & 49.9 & 170.52 & 1661.4 & 1.70 & 0.33 & 0.51 & 930 & 0.09 & 64 & 866 & 10.62 & 4538.0 & 0.014 & 1.29 \\
\hline & 40 & 7.4 & 14.0 & 6.88 & 116.6 & 0.47 & 0.32 & 0.47 & 650 & 0.22 & 40 & 610 & 0.38 & 1409.8 & 0.028 & 0.82 \\
\hline & 39 & 1.2 & 6.4 & 2.77 & 14.9 & 2.27 & 0.24 & 0.37 & 390 & 0.33 & 28 & 362 & 0.14 & 675.7 & 0.041 & 0.56 \\
\hline
\end{tabular}




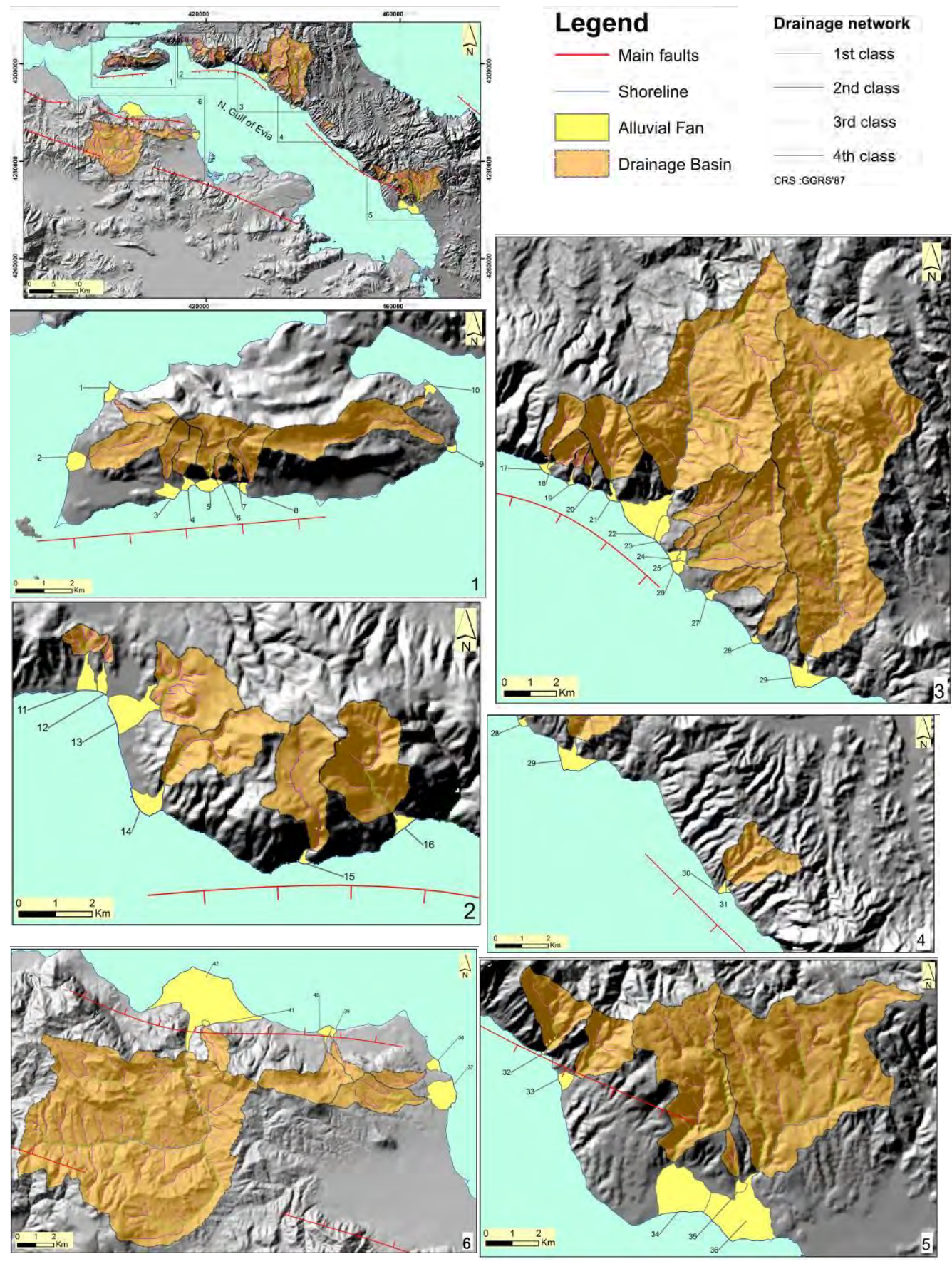

Figure 3- Hillshade map of the North Evoikos Gulf (Gulf of Evia) showing the main faults and the location of the studied fans and their catchments.

\section{Alluvial Fan - Drainage Basin Morphometric Relationships}

The study of the morphomerty of alluvial fans and drainage basins reveals information regarding fan evolution and the dynamics of hydrological processes responsible for fan formation (Harvey, 
1997). The correlation between the geomorphic features of the studied fans and their drainage basins include the investigation of the relationship between basin area and fan delta area, as well as between basin area and fan delta slope.

\subsection{Drainage Area (Ab) versus Fan Area (Af)}

The most commonly compared feature of the alluvial fan and its drainage basin have been their respective areas. Bull (1962) was the first to recognize that as drainage basin area increases, the size of the alluvial fan increases. He quantified the relationship with a simple power function:

$$
A_{f}=c A_{b}{ }^{k} \quad \text { (1) }
$$

where $A_{f}$ is alluvial fan area, $A_{d}$ is drainage basin area and $c$ is an empirical derived coefficient representing the area of an alluvial fan with a drainage basin area of 1.0. The exponent $\mathrm{k}$ is the slope of the regression line and measures the rate of change in fan area with increasing drainage basin area. Comparison of these two parameters offers the most interesting correlation for the total of the coastal fans of the study area. As drainage basin area is the most effective factor for the fan area, the comparison of coarse sediment supply is carried out by use of regression lines between drainage basin areas and fan areas. By representing this relation on a log-log plot (Figure 4a) it becomes clear that the data fit the following single exponential function:

$$
A_{f}=0.12 A_{b}^{0.7} \quad \text { (1.1) }
$$

with a positive correlation coefficient of 0.89 . The reason for this strong positive relation is that sediment discharge out of the catchment increases as drainage area increases. This shows that the size of the contributing basin is an important control on the availability of sediment for transport to the fan.

The coefficient c, which according to Harvey (1997) typically ranges from 0.1 to 2.2 , has the value of 0.12 for the study area. The exponent $\mathrm{k}$ attains the value 0.7 and is in agreement with the aspect that the exponent varies from 0.7 to 1.1 (Harvey, 1997) and that it is generally less than 1.0 (Hooke and Rohrer, 1977). In the literature different values of the exponent $\mathrm{k}$ and the coefficient $\mathrm{c}$ for humid and sub-humid region fans have been reported (Crosta and Frattini, 2004). This variability has been attributed to different factors, such as climate conditions, tectonic setting, and relative erodibility of source area rock types. The variability of the exponent value for the four groups of fans reflects variations in tectonic setting.

The graph of basin area vs. fan area (Figure 4a) shows that while there is a general trend of increasing fan area with increasing basin area, as expected, there is wide variation in fan areas for given basin areas. The variation in fan area attributed to different tectonic setting is hypothesized to be one of the reasons why basin area alone is not a strong predictor of fan area. Another suggested reason is that the morphology of the fans is strongly affected locally by secondary processes (such as coastal erosion) which mobilize and modify sediments previously transported by primary processes.

\subsection{Drainage Area (Ab) versus Fan Slope (Sf)}

Another relationship that has been investigated in the literature is the one between the drainage basin area and the fan gradient (Hooke, 1968; Harvey et al., 1999).

$$
S_{f}=c A_{b}{ }^{k}
$$

The relation between these two parameters for the total number of the fans (Figure $4 \mathrm{~b}$ ) can also fit a potential type function of the following form:

$$
S_{f}=0.06 A_{b}{ }^{-0.23}
$$

The value of the exponent $(-0.23)$ falls within the range of values determined for the majority of examples described by other authors $(-0.35$ to -0.15$)$ (Harvey, 1997) while the coefficient $(0.06)$ is 
in the range of typically reported values $(0.03-0.17)$. The reason for this correlation is that water discharge increases with drainage area resulting in higher flow velocities and bed shear stress. Thus the flow is capable of transporting on a lower slope the same material transported by smaller discharges on a higher slope. Variability among the values of exponent and coefficient for the fans of the four groups can be attributed to different tectonic settings of the fan-catchment systems.
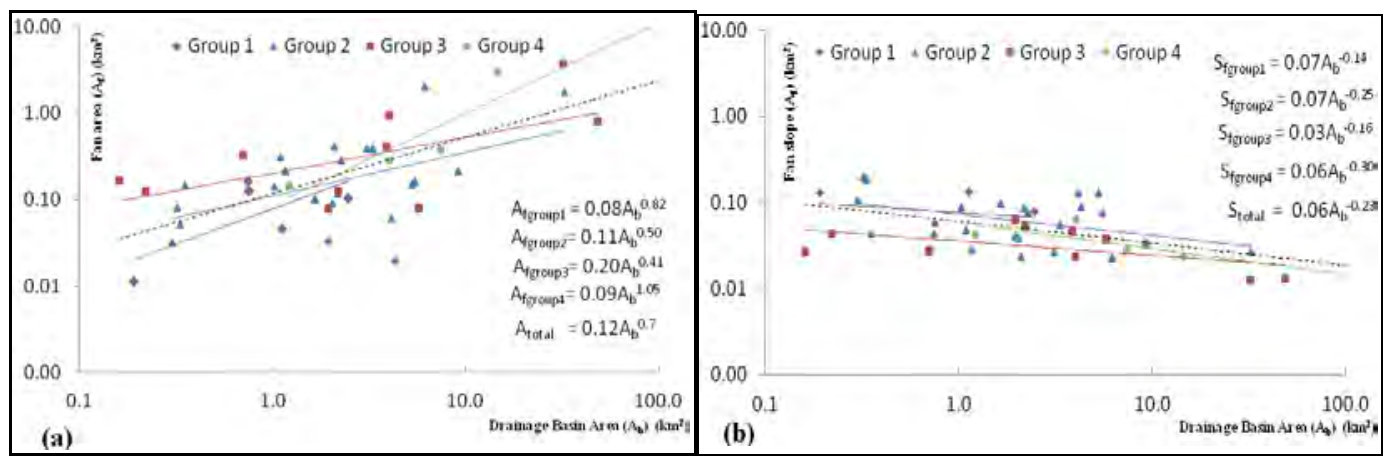

Figure 4 - (a) Drainage basin area vs. Fan area and (b) Drainage basin area vs. Fan slope log $-\log$ plots (dashed lines refer to total of the fans).

All the above mentioned relationships, for each group and for the total of fans, can be summarized in Table 2. Group 4 shows the best correlation coefficient for both functions (Drainage Basin area $\left(\mathrm{A}_{\mathrm{b}}\right)$ vs Fan area $\left(\mathrm{A}_{\mathrm{f}}\right)$ and Drainage Basin area $\left(\mathrm{A}_{\mathrm{b}}\right)$ vs Fan slope $\left(\mathrm{S}_{\mathrm{f}}\right)$ ).

Table 2 - Summary of relationships' functions for each of the four fan groups

\begin{tabular}{|l|c|c|}
\cline { 2 - 3 } \multicolumn{1}{c|}{} & $\begin{array}{c}\text { Drainage Basin } \\
\text { area vs Fan area } \\
\text { (Af) }\end{array}$ & $\begin{array}{c}\text { Drainage Basin } \\
\text { area vs Fan } \\
\text { slope (Sf) }\end{array}$ \\
\hline Group 1 & $\mathrm{A}_{\mathrm{f}}=0.08 \mathrm{~A}_{b}{ }^{0.82}$ & $\mathrm{~S}_{\mathrm{f}}=0.07 \mathrm{~A}_{b}{ }^{-0.14}$ \\
\hline Group 2 & $\mathrm{A}_{\mathrm{f}}=0.11 \mathrm{~A}_{b}{ }^{0.50}$ & $\mathrm{~S}_{\mathrm{f}}=0.07 \mathrm{~A}_{b}{ }^{-0.25}$ \\
\hline Group 3 & $\mathrm{A}_{\mathrm{f}}=0.20 \mathrm{~A}_{b}{ }^{0.41}$ & $\mathrm{~S}_{\mathrm{f}}=0.03 \mathrm{~A}_{b}{ }^{-0.16}$ \\
\hline Group 4 & $\mathrm{A}_{\mathrm{f}}=0.09 \mathrm{~A}_{b}{ }^{1.05}$ & $\mathrm{~S}_{\mathrm{f}}=0.06 \mathrm{~A}_{b}{ }^{-0.30}$ \\
\hline Total & $\mathrm{A}_{\mathrm{f}}=0.12 \mathrm{~A}_{b}{ }^{0.7}$ & $\mathrm{~S}_{\mathrm{f}}=0.06 \mathrm{~A}_{b}{ }^{-0.23}$ \\
\hline
\end{tabular}

\section{Conclusions}

This study deals with the identification and morphometric analysis of alluvial fans and their contributing catchments along the coast of North Evoikos Gulf. Qualitative and quantitative geomorphological observations led to an initial classification of the fans.

Four main fan types with distinct different morphological features, formed in different tectonic settings, were recognized. The first group includes small relatively steep fans likely affected by debris-flow processes. Fan-catchment systems of the second group are located on the footwalls of the main active normal faults and have generally small, short and steep feeder channels due to tectonic uplift. The fans of the third group are "open" with low gradient, and are fluvial-dominated with larger feeder channels. Both fans and corresponding catchments of this group lie between fault segments or near their terminations. Finally, the fourth group includes the more extensive, 
gently sloping fluvial fans that have developed on the hanging walls of major faults formed by extensive basins which are located on the uplifting blocks.

A strong positive relationship between fan area and drainage basin area was identified for the combined group of fans of the study area. The exponential function for the fan area - basin area relationship showed that larger basins supply proportionally less sediment to coastal fans than the smaller ones. Although there is a general trend of increasing fan area with increasing basin area, there is wide variation in fan areas for given basin areas. One of the reasons why basin area alone is not a strong predictor of fan area is hypothesized to be the variations in fan area attributed to different tectonic settings.

\section{Acknowledgments}

We would like to thank Dr. A. Ganas and an anonymous reviewer for their comments and corrections that significantly improved the paper.

\section{References}

Blair T.C. and McPherson J.G. 1994. Alluvial fan processes and forms, in: Abrahams A. D. and Parsons A.J., eds., Geomorphology of Desert Environments. London: Chapman \& Hall, 354-402.

Bull W.B. 1962. Relations of alluvial fan size and slope to drainage basin size and lithology in western Fresno County,CA., U.S. Geological Survey Professional Paper.

Clarke P.J., Davies R.R., England P.C., Parsons B., Billiris H., Paradissis D., Veis G., Cross P.A., Denys P.H., Ashkenazi V., Bingley R., Kahle H.G., Muller M.V. and Briole P. 1998. Crustal strain in central Greece from repeated GPS measurements in the interval 19891997, Geophysical Journal International, 135, 195-214.

Crosta G. and Frattini P. 2004. Controls on modern alluvial fan processes in the central Alps, Northern Italy, Earth Surface Processes and Landforms, 29, 267-293.

Cundy A. B., Gaki-Papanastassiou K., Papanastassiou D., Maroukian H., Frogley M. R., and Cane T. 2010. Geological and geomorphological evidence of recent coastal uplift along a major Hellenic normal fault system (the Kamena Vourla fault zone, NW Evoikos Gulf, Greece), Marine Geology, 271, 156-164.

Cundy A.B., Kortekkas S., Dewez T., Stewart I., Crousace W., Maroukian H., Papanastassiou D., Gaki-Papanastassiou P., Pavlopoulos K. and Dawson A. 2000. Coastal impacts of the 1894 Gulf of Atalanti earthquakes, Cental Greece, Marine Geology, 170, 3-26.

Gaki-Papanastassiou K., Maroukian H., Papanastassiou D. and Palyvos N. 1999. Archaeogeology and morphotectonics of the area of Livanates-Kynos-Arkitsa during the Holocene. 5th Greek Geographical Congress, Athens 11-13 November, 1999, 101-111.

Ganas A. and White K. 1996. Neotectonic fault segments and footwall geomorphology in the Eastern Central Greece from Landsat TM data. Geological Society Greece Sp. Pub., 6, 169175.

Ganas A. and Papoulia I. 2000. High-resolution, Digital Mapping of the Seismic Hazard within the Gulf of Evia Rift, Central Greece Using Normal Fault Segments as Line Sources, Natural Hazards, 22 (3), 203-223.

Goldsworthy M., Jackson J. and Haines J. 2002. The continuity of active fault systems in Greece, Geophysical Journal International, 148(3), 596-618.

Goldsworthy M. and Jackson J. 2001. Migration of activity within normal fault systems: examples from the Quaternary of mainland Greece, Journal of Structural Geology, 23, 489-506.

Harvey A. M., Silva P.G., Mather A. E., Goy J. L., Stokes M. and Zazo C. 1999. The impact of Quaternary sea-level and climate change on coastal alluvial fans in the Cabo de Gata ranges, southeast Spain, Geomorphology, 28, 1-22. 
Harvey A. M. 1997. The role of alluvial fans in arid zone fluvial systems. In: Thomas D.S.G. (eds.), Arid Zone Geomorphology: Process, Form and Change in Dry lands, John Wiley and Sons Limited, Chichester, 231-259

Hooke R. L. and Rohrer W. L.1977. Relative erodibility of source area rock types from second order variation in alluvial fan size. Geological Society of America Bulletin, 88, 1177-1182.

Hooke R. L. B. 1968. Steady-state relationships on arid region alluvial fans in closed basins, Ammerican Journal of Science, 266, 609-629.

IGME, 2010. Hydrolithological map, scale 1:200,000, Project "Definition and assessment of hydrogeological characteristics of aquifer systems of Greece, Water district of E. Central Greece", IGME, Division of water resources and environment, Department of Hydrogeology, Compilation by Dandolos, E., Zorapas, V.

Karymbalis E., Giles P., Ferentinou M. and Gaki-Papanastassiou K.. 2012. Analysis of relationships among morphometric parameters of coastal alluvial fans and source basins in North Peloponnese, Greece. Proceedings of the 16th Joint Geomorphological Meeting (Rome), 91-94.

Karymbalis E.,Gaki-Papanastassiou,K. and Ferentinou M. 2010. Fan deltas classification coupling morphometric analysis and artificial neural networks : The case of NW coast of Gulf of Corinth, Greece, Hellenic Journal of Geosciences, 45, 133-146.

Karymbalis E. 2007. Fan Deltas Geomorphology in the Northern Coast of Gulf of Corinth, Greece, Proceeding of the Eighth International Conference on the Mediterranean Coastal Environment, MEDCOAST 07, Alexandria, Egypt, 13-17 November 2007, 1321-1332

Leeder M. and Jackson J. 1993. The interaction between normal faulting and drainage in active extensional basins, with examples from the western United States and central Greece, Basin Research, 5, 79-102.

Palyvos N., Bantekas I. and Kranis H. 2006. Transverse fault zones of subtle geomorphic signature in northern Evia island (central Greece extensional province) : An introduction to the Quaternary Nileas graben. Geomorphology, 76, 363-374.

Pantosti, D.,De Martini P.M.,Papanastassiou D.,Lemeille F.,Palyvos N., and Stavrakakis G. 2004. Paleoseismological trenching across the Atalanti fault (Central Greece): Evidence for the ancestors of the 1894 earthquake during the middle ages and Roman times, Bull. Seism. Soc. Am., 94, 531-549.

Papanastassiou D. Stavrakakis G. and Makaris D. 2001. Recent micro-earthquake activity at Northern Evoikos Gulf, Central Greece. Bulletin of the Geological Society of Greece, Proceedings of the 9th Inernational Congress, Athens, XXXIV/4, 1567-2572.

Papoulia J.,Makris J. and Drakopoulou V.2006. Local seismic array observations at north Evoikos, central Greece, delineate crustal deformation between the North Aegean Trough and Corinthiakos Rift, Tectonophys. 423, 97-106.

Pavlides S.B., Valkaniotis S., Ganas A., Keramydas D. and Sboras S. 2004. The Atalanti active fault: Re-evaluation using new geological data, Bulletin of the Geological Society of Greece, Proceedings of the 10th Inernational Congress, Thessaloniki, XXXVI/4, 15601567.

Roberts S. and Jackson J. 1991. Active normal faulting in central Greece: an overview. In: A. M. Roberts, G. Yielding and B. Freeman (eds.). The Geometry of Normal Faults. London: Geological Society Spec. Pub.56.

Rozos D., Skilodimou H. D., Loupasakis C. and Bathrellos G. D. 2013. Application of the revised universal soil loss equation model on landslide prevention. An example from N. Euboea (Evia) Island, Greece, Environmental Earth Sciences.

Stiros S. C., Arnold M., Pirazzoli P. A., Laborel F. and Papageorgiou S., 1992. Historical coseismic uplift on Euboea island, Greece, Earth and Planetary Science Letters, 108, 109-117. 